\title{
ELF3 Gene
}

National Cancer Institute

\section{Source}

National Cancer Institute. ELF3 Gene. NCI Thesaurus. Code C20899.

This gene is involved in the regulation of both transcription and epithelial cell differentiation. It also plays a role in angiogenesis. 